\title{
Effect of Foliar application of GA3 and NAA for reducing alternate bearing of olive trees (Olea europaea L. cv.Ashrasie)
}

\author{
1- Shabaq M. Nafea, ${ }^{2-}$ Halala K. Abdulfatah \\ Horticulture Dept., College of Agriculture/ University of Salahaddin, Erbil//raq
}

\begin{abstract}
The economic main importance's of olives are; oil and pickle olives. Olive cultivation can be successfully carried out in Iraq, Ashrasie, is one of the most common olive, which is mainly used for green pickles, as foliar application on the trees Gibberellic acid (GA3) (75, 100 and 125) mg..$^{-1}$, Naphthaleneacetic acid (NAA) $(50,100) \mathrm{mg}^{-l^{-1}}$ in addition of control was done after 15 days after fruit set for two season 20092010, 2010-2011, fruit harvested at mid-October. The effect of growth regulators (GA3, NAA) was not uniform in different treatments. However, GA3 $(100,125) \mathrm{mg}^{-l^{-1}}$ in combination with NAA $(50,100) \mathrm{mg}^{\mathrm{l}^{-1}}$ gave maximum value of most physical characteristics and fruit set and yield and oil of olive trees cv. ashrasie.
\end{abstract}

Key words: Concentration, Foliar, GA3, NAA, Olive

\section{Introduction}

Alternate bearing is a built-in character of olive trees. It is over all controlled by an interaction between vegetative growth and fruit load. The expression of alternate bearing involves a wide range of changes in activation and repression of endogenous metabolic pathways. The economic main importance's of olives are; oil and pickle olives. Olive cultivation can be successfully carried out in Iraq, Ashrasie, is one of the most common olive, which is mainly used for green pickles, Fruit has elliptical shape, with the base similar to apple is circular, medium to big size at maturation, and irregular white flecks circular on the fruit surface, pith color is yellowish white, mellow, and medium in length (Al-Sabbagh,1980), (Hamzah, 1985), (Al-Khafaji et al., 1990), (Agha and Daoud, 1991), (Mohammed and Ibrahim, 2008). Olives are well known to produce crops in alternateyear cycles ((Daood, 2002; Krueger et al., 2004; Lavee, 1996). The heavy crop loads of "on" seasons give rise to fruit of a very poor quality (i.e., small fruit size in the case of 'Barouni' and other table olive cultivars) (Krueger et al., 2004).

Spray olive trees with Gibberellic acid( GA3) before an expected "on" year decreased the percentage of opened flower buds per shoot, number of flowers per inflorescence in the subsequent year. (Hassan, 1987; Lavee and Haskal, 1994) and (El-Iraqy, 2001), GA are responsible for cell elongation, rather than cell division (Francis and Sorrell, 2001).

GA3 succeeded in inhibition of olive tree blooming in the following season, (El-Sharkawy, 1999). GA3 has the potential control on growth and flowering process. In addition, increased petiole length, leaf area and delayed petal abscission and color fading (senescence) by the hydrolysis of starch and sucrose into fructose and glucose (Khan and Chaudhry, 2006; Emongor, 2004), GA3 treatments increase the weight, length, width of olive fruits, stone weight and flesh weight than untreated ones, (Rotundo and Gioffre, 1984), improvement fruit weight and flesh: seed ratio, (Barut and Eris, 1995; Ramezani and Shekafandeh, 2009).

Naphthaleneacetic acid, commonly abbreviated NAA is an organic compound, which is a plant hormone in the auxin family and is an ingredient in many commercial horticultural products; it is also a rooting agent and used for the vegetative propagation of plants from stem and leaf cutting (Dimitrios et al., 2008). NAA has been reported to be useful for thinning of fruits (Agusti et al., 2000). It has important role in fruit formation, abscission cell elongation, apical dominance, photoperiod and geotropism (Haidry et al., 1997). NAA application at $(100,150) \mathrm{mg} \mathrm{L}^{-1} 15$ days after full bloom has been used to chemically thin olives in various countries, (Lavee, 2006).

The main objective of this study was to study the effect of GA3 and NAA on reducing the alternate bearing severity for Ashrasie olive.

\section{Material and Methods}

The present study was carried out for two seasons 2009/2010, 2010/2011 on olive orchard at the Engineering College, University of Salahaddin- Erbil, Kurdistan, Iraq, located on 36007`N, 44o10`E and 415m (amsl*), The soil was a sandy silt loam (according to Smith and Mullins, 2001).

Numbers of replicates were two trees as replicate, trees of twenty-five years old $(7 \times 7 \mathrm{~m})$, Ashrasie cultivar were used, each 24 uniform size trees distributed randomly among the 12 treatments; it was set in a completely randomized block (RCBD) design. each three replicates were treated with Gibberellic acid (GA3) $(75,100,125)$ 
mg. $1^{-1}$ and 1-Naphthaleneacetic acid (NAA)(50,100) mg.1 ${ }^{-1}$ were applied alone and in combination, In addition to control (tap water) which were applied, 15 days after fruit set, as foliar application on the trees.

Twee 20 used as a publisher of a concentration 1\%. Normal cultural practices, such as pruning, suckers removing, cultivation and weed control were performed (Chandler, 1958; Hassan, 1995). The collected data subjected to analysis of variance and means separated by Duncan's Multiple Range test (Al-Rawi and Khalafullah, 1980). Fruit harvested at the normal time and ripening stage for the area(mid-October) when about $75 \%$ of the olives reached purple colour The field measurements included: Fruit size of the 100 randomly selected fruits measured by cylinder method, Fruit weight (g) as the average of 100 fruits (selected randomly) taken by electronic balance, stone weights $(\mathrm{g})$ were taken after removing and air drying of 100 random fruits by sensitive balance, Weight of pulp (g)given as ( Weight of pulp (g) = Average fruit weight - average stone weight), Pulp: Stone ratio given as:

Average pulp weight

Pulp : Stone ratio = ----------------

Yield olives were harvested at mid-October every season when about $75 \%$ of the olives reached purple colour, fruits of each tree were separately harvested, then weighed and yield as Kg.tree ${ }^{-1}$ was estimated (Jose et al, 1996). (Wood, 1989) reported that alternate bearing index (ABI) ranged from 0 to 1.0. If $A B I=0$, there is no alternate bearing and if $\mathrm{ABI}=1.0$, there is a complete alternate bearing. Therefore, if the alternate bearing index would be close to 1 , the differences in crop production between two years are very high. Fruit Oil \% determined by the soxhlet extraction (diethyl ether) method, according to A.O.A.C (1975).

\section{Results And Discussion}

\section{1- Effect of foliar application of GA3 and NAA and interaction between them on physical characteristics of Olive fruit in 2009 and 2010 seasons}

Foliar application treatments had pronounced effect on improving fruit quality, data in Table (1) showed that physical characteristic of olive fruit cv. Ashrasie was greatly affected by most treatments, fruit weight is one of the parameters characterizing the quality of the olive, and results demonstrated significant increase in fruit size by interaction between GA3 sprays with NAA at any concentration compared with control and another treatment. Maximum fruit size was $(4.36,4.46) \mathrm{cm}^{3}$ found in treatment (GA3100+NAA 100) mg. $\mathrm{l}^{-1}$ while smallest fruit size was in control $(2.82,291) \mathrm{cm}^{3}$ in the two years of the study respectively. The results are in agreement with that obtained by (Barros, 1992; Khalil et al., 2012) they reported that application of GA3 alone or in combination increased the fruit diameter.

Fruit weight increased significantly when treated with different concentrations of GA3 and NAA (alone or in combination) compared with control in two years of study. (Table 1) showed that maximum fruit weight was $(4.00,4.36) \mathrm{g}$ in (GA3 100 +NAA 100) $\mathrm{mg}^{-1} \mathrm{l}^{-1}$ while minimum fruit weight was observed in control (2.86, $2.95) \mathrm{g}$. These results are in agreement with those of improvement fruit weight and flesh: seed ratio (El-Iraqy, 2001; Ramezani and Shekafandeh, 2009).

Table (1) showed Increase in the weight pulp of fruit, all treatments performed differently and showed significant difference for fruit pulp weight, it is due to increase of fruit weight. Maximum pulp weight was $(3.36,3.67) \mathrm{g}$ in (GA3 $100+$ NAA 50) $\mathrm{mg} . \mathrm{l}^{-1}$ while minimum $(2.02,2.10) \mathrm{g}$ was observed in control in two years respectively. Zhang et al. (2007) expressed that increased sink demand by induced application of GA is closely related to the activation of invertase cell wall-bound in the core and invertase neutral and NAD-dependent sorbitol dehydrogenase in the pulp during rapid fruit growth in fruit.

The results in Table (1) cleared that spraying Ashrasie olive trees with GA3 either individually or in combination with NAA slightly significantly decreased fruit stone weight and increased pulp fruit/stone ratio than those of control treatment in the two seasons of study 

Table (1) Effect of foliar application of GA3 and NAA on physical
characteristics of olive fruit cv. Ashrasie in 2009 and 2010 seasons



A same letter in the column indicates that there is no significant difference $(\mathrm{p}<0.05)$.

\section{2- Effect of foliar application of GA3 and NAA and interaction between them on yield and alternate bearing of Olive fruit in 2009 and 2010 seasons.}

Results in table (2) showed that final fruit set of Ashrasie olive trees were significantly affected by different concentrations of GA3 in the two seasons. In addition, increased by spray GA3 $100 \mathrm{mg} . \mathrm{l}^{-1}$ in combination with NAA $75 \mathrm{mg} . \mathrm{l}^{-1}$ those under control and NAA $75 \mathrm{mg} . \mathrm{l}^{-1}$. However, the control gave the

lowest final fruit set in both seasons. Also, this was on a par with (GA3 100 +NAA 100) mg.1 $1^{-1}(3.23,3.64)$

$\%$ respectively. (El-Shewy, 19999; Daood, 2002; Abdrabboh,2013 ). Chaari-Rkhis et al. (2006) reported that gibberellic acid play an important role in the induction of flowering process in olive tree. Decreasing fruit set ratio in control do not achieve any increase in fruit yield $(\mathrm{kg})$, the effect of GA3 on cell elongation and NAA on cell division, as shown in the results of table (2) spraying olive trees with (GA3 $100 \mathrm{mg} . \mathrm{l}^{-1}+$ NAA) $100 \mathrm{mg} . \mathrm{l}^{-1}$ significantly increased the yield of both season as compared with most treatments, while control gave the lower yield, these results reflected in the value of index of alternate bearing the highest value was in control (0.230).

Changes in fruit parameters will be directly reflected into the quantity and quality of the olive yield, the data of both seasons presented in tables (2) indicated that there are significant differences between olive fruits from trees treated with growth regulators and control samples in oil \% content. The dynamic relationship between fruit load and fruit size in two years was a significant compensation factor in fruit and oil yields. In both seasons, fruit size in control $(2.82,2.91) \mathrm{cm}^{3}$ is smaller than in other treatments, is likely to provide consistent yearly oil yields ranging from (25.76 to 30.37$) \%$ in the first year and (44.55 to 44.04$) \%$ in the second year. The results demonstrate the possibility of using GA3 in combination NAA with post-bloom spraying to balance biennial bearing in olive oil. The results are in agreement with that obtained by (Abd ElNaby et al, 2012; Abdrabboh, 2013) working on olive trees, they reported that GA3 greatly increased fruit oil percentage compared with control, while the results are not agreement with (EL Badry, 2012). 
Table (2) Effect of foliar application of GA3 and NAA on Yield of olive fruit cv. Ashrasie in 2009 and 2010 season

\begin{tabular}{|c|c|c|c|c|c|c|c|}
\hline \multirow[b]{2}{*}{ Treatment } & \multicolumn{2}{|c|}{$\begin{array}{c}\text { Fruit set at harvest } \\
\%\end{array}$} & \multicolumn{2}{|c|}{$\begin{array}{l}\text { Fruit yield } \\
\left(\mathrm{Kg} \text { tree }^{-1}\right)\end{array}$} & \multirow[t]{2}{*}{$\begin{array}{c}\text { Index of altemat } \\
\text { bearing }\end{array}$} & \multicolumn{2}{|c|}{$\begin{array}{c}\text { Oil yield } \\
\%\end{array}$} \\
\hline & 2009 & 2010 & 2009 & 2010 & & 2009 & 2010 \\
\hline Control & $2.89 \mathrm{~d}$ & $3.72 \mathrm{~cd}$ & $15.07 \mathrm{~d}$ & $24.08 \mathrm{abc}$ & 0.230 & $25.76 d$ & $30.37 \mathrm{~cd}$ \\
\hline $75 \mathrm{mg}^{-1} \mathrm{I}^{-1} \mathrm{GA}_{3}$ & $3.46 \mathrm{bc}$ & $4.12 \mathrm{bc}$ & $16.72 \mathrm{~cd}$ & $20.63 c$ & 0.105 & $37.44 \mathrm{ab}$ & $37.68 \mathrm{bc}$ \\
\hline $100 \mathrm{mg}^{-1} \mathrm{l}^{-1} \mathrm{GA} 3$ & $3.56 \mathrm{bc}$ & $4.38 \mathrm{~b}$ & $17.90 \mathrm{~cd}$ & $22.36 \mathrm{bc}$ & 0.111 & 44.55 a & $40.77 b$ \\
\hline $125 \mathrm{mg} \cdot \mathrm{I}^{-1} \mathrm{GA} 3$ & $4.58 \mathrm{ab}$ & $4.98 \mathrm{a}$ & $17.14 \mathrm{~cd}$ & $21.59 \mathrm{bc}$ & 0.115 & $38.69 \mathrm{ab}$ & $30.17 \mathrm{~cd}$ \\
\hline $50 \mathrm{mg}^{-1} \mathrm{IAA}$ & $3.16 \mathrm{~cd}$ & $3.42 \mathrm{~d}$ & $18.53 \mathrm{~cd}$ & $26.50 \mathrm{ab}$ & 0.177 & $36.15 \mathrm{ab}$ & $31.06 \mathrm{~cd}$ \\
\hline $100 \mathrm{mg}^{-1} \mathrm{I}^{-1} \mathrm{NAA}$ & $3.5 \mathrm{bc}$ & $3.81 \mathrm{c}$ & $16.64 \mathrm{~d}$ & $23.38 \mathrm{bc}$ & 0.168 & $37.40 \mathrm{ab}$ & $30.01 \mathrm{~cd}$ \\
\hline $75 \mathrm{mg} \cdot \mathrm{l}^{-1} \mathrm{GA}_{3}+50 \mathrm{mg} \cdot \mathrm{l}^{-1} \mathrm{NAA}$ & $3.18 \mathrm{~cd}$ & $3.89 \mathrm{c}$ & $18.11 \mathrm{~cd}$ & $25.20 \mathrm{ab}$ & 0.164 & $35.71 \mathrm{ab}$ & $36.11 b c$ \\
\hline $75 \mathrm{mg} \cdot 1^{-1} \mathrm{GA}_{3}+100 \mathrm{mg} \cdot \mathrm{l}^{-1} \mathrm{NAA}$ & $3.96 \mathrm{~b}$ & $4.17 \mathrm{bc}$ & $17.92 \mathrm{~cd}$ & $20.11 \mathrm{c}$ & 0.058 & 38.23 ab & $34.94 \mathrm{c}$ \\
\hline $100 \mathrm{mg} \cdot \mathrm{I}^{-1} \mathrm{GA} 3+50 \mathrm{mg} \cdot \mathrm{I}^{-1} \mathrm{NAA}$ & $4.01 \mathrm{~b}$ & $4.75 a b$ & $20.65 \mathrm{bc}$ & $24.58 a b c$ & 0.087 & $30.72 \mathrm{c}$ & $34.99 \mathrm{c}$ \\
\hline $100 \mathrm{mg} \cdot \mathrm{I}^{-1} \mathrm{GA}+100 \mathrm{mg} \cdot \mathrm{I}^{-1} \mathrm{NAA}$ & $4.78 \mathrm{a}$ & $5.05 a$ & 26.74 a & $28.56 \mathrm{a}$ & 0.033 & $37.37 \mathrm{ab}$ & $40.69 \mathrm{~b}$ \\
\hline $125 \mathrm{mg} \cdot \mathrm{I}^{-1} \mathrm{GA}+50 \mathrm{mg} \cdot \mathrm{I}^{-1} \mathrm{NAA}$ & $4.62 \mathrm{ab}$ & $4.87 a b$ & $22.91 \mathrm{ab}$ & $24.39 a b c$ & 0.031 & $36.36 \mathrm{a} a \mathrm{~b}$ & $39.59 \mathrm{~b}$ \\
\hline $125 \mathrm{mg} \cdot 1^{-1} \quad \mathrm{GA}+100 \mathrm{mg} \cdot \mathrm{l}^{-1} \mathrm{NAA}$ & $3.23 \mathrm{~cd}$ & $3.64 \mathrm{~cd}$ & $23.68 \mathrm{ab}$ & $20.42 c$ & 0.091 & $42.73 a$ & $44.04 \mathrm{a}$ \\
\hline
\end{tabular}

A same letter in the column indicates that there is no significant difference $(\mathrm{p}<0.05)$.

\section{References}

[1] Abd El-Naby, S.K.M.; El-Sonbaty, M.R. Hegazi, E.S. Samira, M.M. and El- Sharony, T.F., 2012. Effect of Gibberellic acid spraying on alternate bearing of Olive trees. J. Appl. Sci. Res., 8(10): 5114-5123.

[2] Abdrabboh, G. A., 2013. Effect of Some Growth Regulators on Yield and Fruit Quality of Manzanillo Olive Trees. Nature and Science 2013; 11 (10): 143-151.

[3] Agha, J. T. and Daoud A. Daoud., 1991. Evergreen Fruit Production. Part I, Mousul Univ. Iraq, pp. 567-630(In Arabic).

[4] Al-Khafaji, M.A, S.A.Atra and A.A.Mohammad., (1990): Evergreen Fruits. Baghdad Univ. Ministry of higher education and scientific research Baghdad. Iraq.pp. 229-273(In Arabic).

[5] Al- Sabbagh, S.S.M., (1980): Olive growing. Ministry of Agriculture, Baghdad, Iraq. 7p. (In Arabic)

[6] A.O.A.C., 1975: Official methods of Analysis. P.W. Howtry. AOAC, Washington D.C. U.S.A.

[7] Barut, E. and A. Eris, 1995. Research on the effect of girdling, thinning and plant growth regulators on yield, quality and alternate bearing in olive cv. Gemlik.

[8] Chaari-Rkhis, A. Maalej, M. Ouled Messaoud, S. and Drira, N.2006. In vitro vegetative growth and flowering of olive tree in response to GA3 treatment. Afri. J. Biotech. 5:2097- 2102. Doga Turk rim ve Ormancilik Dergisi, 17(4): 953-970. Cited from Hort. Abst., 65: 4544 .

[9] Daood, E.Z., 2002. Studies on fruit setting, development, ripening and improvement quality of olive. Ph.D. Thesis Ain Shams Univ. Egypt.

[10] Dimitrios, P.N., I.C. Tzanetos, P.N. Georgia and P. Nikos, 2008. A portable sensor for the rapid detection of naphthalene acetic acid in fruits and vegetables using stabilized in air lipid films with incorporated auxin-binding protein 1 receptor. Talanta, 77: 786- 792 .

[11] Mohammed Bahram Kh. and Ibrahim M. Noori, 2008. Effect of Irrigation levels on the growth and yield of olive trees (Olea europaea L. cv.Ashrasie). Journal of Kirkuk University - Scientific Studies, vol.3, No.1:169-183.

[12] EL Badry., 2012. Physiochemical Characteristics and Quality Criteria of Olive Oil Extracted from Picual Olive Fruits Treated by Some Growth Regulators Middle East Journal of Applied Sciences, 2(1): 37-50, 2012: 37-50.

[13] El-Iraqy, M., 2001. Physiological Studies on Alternate Bearing Of Olive. Ph.D Thesis, Fac. Agric., Zagazig Univ., Egypt, pp.: 148.

[14] El-Sharkawy, S.M., 1999. Physiological Studies On Flowering And Fruiting Of Olive Tree. Ph.D. Thesis, Fac. Agric., Moshtohor Zagazig Univ., Egypt, pp: 168

[15] El-Shewy, A. A., 1999. Response of guava trees to some chemical substances sprays. Annals of Agric. Sci., Moshtohor. 37:3, 1649- 1661.

[16] Emongor, V.E., 2004. Effect of gibberellic acid on postharvest quality and vase life of gerbera cut flowers (Gerbera jamesonii). J. Agron., 3: 191- 195.

[17] Faisal, Khalil Mahmood Qureshi, Ammaz Khan, Fakhar-ul-Hassan and Nabila Bibi., 2012. Effect of girdling and plant growth regulators on productivity in olive (Olea europaea). Pakistan J. Agric. Res. Vol.25 No.2, 120-128.

[18] Francis, D \& Srrell, D.A., 2001. The interface between the cell cycle and plant growth

[19] Regulators: a mini review. Plant Growth Regul. 33. 1-12. 
[20] Khan, A.S. and N.Y. Chaudhry, 2006. GA3 improves flower yield in some cucurbits treated with lead and mercury. Afr. J. Biotechnol., 5: 149-153.

[21] Haidry, G. A. Jalal-ud-Din and Munir, M., 1997. Effect of NAA on fruit drop yield and quality of mango, Mangifera indica cultivars Langra. Scientific Khyber, 10 (1): 13- 20.

[22] Hamzah, Y.A. Al-Hussein., 1985. Effect of Ethrel and Alsol on olive fruit harvesting (Olea europaea L.). M.Sc. Thesis. Baghdad Univ. Iraq. (In Arabic).

[23] Hassan, L.H.O., 1987. Effect of Some Growth Substances on Flowering And Fruiting of Olive Trees. Ph.D. Thesis, Fac. Agric., Ain Shams Univ., Egypt, pp: 157.

[24] Khan, A.S. and N.Y. Chaudhry. 2006. GA3 improves flower yield in some cucurbits treated with lead and mercury. Afr. J. Biotechnol., 5: 149-153.

[25] Hamzah, Y.A. Al-Hussein., 1985. Effect of Ethrel and Alsol on olive fruit harvesting (Olea europaea L.). M.Sc. Thesis. Baghdad Univ. Iraq. (In Arabic).

[26] Jose M. Garcia, Silvia Seller and M. Carmen Perez-Camino., 1996. Influence fruit ripening on olive oil quality. J. Agric. Food Chem., 44(11): 3516-3520.

[27] Krueger, W.H., Maranto, J. \& Sibbett, G.S., 2004. Olive fruit thinning. In: Olive Production Manual. Sibbett, G.S. \& Ferguson, L. (Ed.) Pp. 101-104. University of California, Oakland, California, USA.

[28] Lavee, S., 2006. Biennial bearing in olive (Olea europaea L.). FAO Network. Olea 25: 5-12. July 2.

[29] Lavee, S. and A. Haskal., 1994. Partial fruiting regulation of Olive trees (Olea europaea L.) with paclobutrazol and gibberellic acid in the orchard. Advances in Horticulture Science, 7(2): 83-86. Cited from Hort. Abst., 64: 1441.

[30] Ramezani, S. and A. Shekafandeh., 2009. Roles of gibberellic acid and zinc sulphate in increasing size and weight of Olive fruit. African Journal of Biotechnology, 8 (24): 6791-6794.

[31] Rotundo, A. and D. Gioffre, 1984. The effect of gibberellic acid (GA3) on the productivity of two Olive cultivars. Tecnica Agricola, 34(3): 187-202.

[32] Smith, K.A. and C.E. Mullins., 2001: Soil and Environmental analysis: Physical Methods. 2nd ed. Revised and Expanded. Marcel Dekker, Inc.637p.

[33] Wood, B.W., 1989. Pecan production responds to root carbohydrates and rootstock. Journal of the American Society for Horticultural Science, 223-228.

[34] Zhang C, Tanabe K, Tani H, Nakajima H, Mori M, Itai A, Sakuno E., 2007. Biologically active gibberellins and abscisic acid in fruit of two late-maturing Japanese pear cultivars with contrasting fruit size. J. Am. Soc. Horticult. Sci. 132: $452-458$. 